\title{
Recruitment of striped bass in Chesapeake Bay: spatial and temporal environmental variability and availability of zooplankton prey
}

\author{
E. J. Martino ${ }^{1,2, *}$, E. D. Houde ${ }^{1}$ \\ ${ }^{1}$ University of Maryland Center for Environmental Science, Chesapeake Biological Laboratory, 1 Williams Street, Solomons, \\ Maryland 20688, USA \\ ${ }^{2}$ Present address: National Oceanic and Atmospheric Administration, Cooperative Oxford Laboratory, Oxford, \\ Maryland 21654, USA
}

\begin{abstract}
Causes of recruitment variability in young-of-the-year (YOY) striped bass Morone saxatilis from Chesapeake Bay were investigated based on (1) surveys from 2001 to 2003 to document spatio-temporal variability in abundance of larval striped bass, zooplankton prey, and feeding success of larvae; (2) a synthetic analysis (1996, 1998, 1999, 2001 to 2003) to describe how environmental factors and prey affect recruitment success; and (3) a 10 yr analysis (1993 to 2002) of inter-annual differences in spatial and temporal patterns of copepods and cladocera eaten by striped bass larvae. Striped bass YOY recruitment levels varied $>11$-fold in the 6 years examined. In those years, mean daily freshwater flows from the Susquehanna River to the bay in March and April varied $>2$-fold and controlled distribution and apparent survival of striped bass larvae. Strong recruitments of YOY striped bass were associated with matches in space and time of larval striped bass and high concentrations of zooplankton prey, especially the copepod Eurytemora affinis and cladoceran Bosmina longirostris. The strongest year classes $(1996,2003)$ were produced in years of high freshwater flow, characterized by a high abundance of feeding-stage larvae and a spatio-temporal match between peak abundance of larvae and zooplankton prey. Enhanced feeding opportunities were most pronounced in high freshwater-flow years $(1996,1998,2003)$, when larvae and zooplankton prey were strongly associated with, and apparently retained near, the estuarine turbidity maximum. First-feeding larvae fed more successfully in a high-flow year $(2003$; prey incidence $91 \%$ ) than in a drier year (2001; prey incidence $35 \%$ ). A regression model that may have forecasting potential was developed to describe recruitment of YOY striped bass for the years from 1985 to 2006. The model includes spring freshwater flow and air temperatures to predict age- 0 striped bass recruitment strength $\left(R^{2}=0.65\right)$. Flow and temperature control environmental and hydrographic conditions that strongly influence spatio-temporal overlap of larval striped bass and zooplankton. The model provided accurate recruitment forecasts for 2007 and 2009, but was less successful in 2008, a year of exceptionally low recruitment.
\end{abstract}

KEY WORDS: Chesapeake Bay · Striped bass $\cdot$ Recruitment variability $\cdot$ Larval fish $\cdot$ Zooplankton · Trophodynamics $\cdot$ Biophysical interactions

Resale or republication not permitted without written consent of the publisher

\section{INTRODUCTION}

Research on recruitment variability has emphasized the connection between larval fish survival and prey availability since Hjort (1914) proposed a critical period at the onset of larval feeding as the determinant of year-class strength. The match-mismatch hypothesis refined the critical period hypothesis by incorporating the degree of temporal overlap between the spring zooplankton bloom and larval production as a critical determinant of recruitment strength (Cushing 1990). Together, these hypotheses have motivated research on recruitment variability in fishes for decades. Implicit in both hypotheses is the recognition that higher prey concentrations lead to enhanced encounter rates between larvae and prey, 
leading to higher larval growth rates and increased larval survival (Houde 2008).

Spatial variability in the prey available to larvae, while not explicitly formalized in critical period and match-mismatch hypotheses, is recognized as a determinant of growth and survival. Feeding conditions of larval fish across mesoscale ( $>1$ to $100 \mathrm{~km}$ ) gradients in prey concentrations are often attributable to prevailing circulation patterns, frontal features, and interacting spatial dynamics of predators and prey (Munk 2007). A spatial mismatch with negative consequences for growth and survival may occur if peak concentrations of larvae and prey do not coincide (Chick \& Van Den Avyle 1999a). Despite supportable hypotheses and tests to link year-class strength of fishes and prey availability, challenges result from contrasts between the spatial and temporal scales over which fish larvae perceive and react to prey and the scales at which they are surveyed (Pepin 2004).

For striped bass Morone saxatilis, abundance of age0 juveniles (i.e. young-of-the-year [YOY] recruitment level) is strongly associated with the abundance of larval survivors at from 8 to 10 mm length (Uphoff 1989, Rutherford et al. 1997), indicating that dynamics in the larval stage coarsely govern recruitment success in Chesapeake Bay. In a synthesis of larval mortality and growth conducted on 5 annual cohorts of striped bass larvae (Houde 1996, 1997), dynamics of cohort production in the bay were variable and sensitive to environmental conditions. Cohorts that accumulated biomass while in the smallest size classes had a higher potential for strong YOY recruitment.

Links between larval striped bass growth, survival, and prey availability have been investigated in field (Setzler-Hamilton et al. 1987, Rutherford \& Houde 1995, Limburg et al. 1999), laboratory (Eldridge et al. 1982, Tsai 1991), and modeling (Logan 1985, Cowan et al. 1993) research. Growth and survival were positively associated with zooplankton when compared across locations in Lake Marion, South Carolina (Chick \& Van Den Avyle 1999a). In the Hudson River, striped bass larvae co-occurring with a bloom of the cladoceran Bosmina freyi showed higher survival rates than larvae temporally mismatched with prey (Limburg et al. 1999). There is evidence indicating that prey availability is important in shaping yearclass success in Chesapeake Bay striped bass, although most is correlative, with years of high prey abundance often coinciding with high recruitment (Rutherford et al. 1997). An individual-based modeling study on egg-, larva-, and juvenile-stage striped bass in the Potomac River tributary of Chesapeake Bay supported the hypothesis that variability in prey availability to larvae could generate 10-fold recruitment variability (Cowan et al. 1993).
A relationship between meteorological conditions and Chesapeake Bay striped bass recruitment strength has been recognized for decades (Merriman 1941). In the 1970s, it was postulated that there is a positive association between cold conditions in the spring and recruitment of anadromous fishes (Mihursky et al. 1981). Other research on recruitment variability in Chesapeake Bay striped bass evaluated temperature and precipitation as factors affecting the survival of weekly egg and larval cohorts (Ulanowicz \& Polgar 1980, Rutherford \& Houde 1995, Secor \& Houde 1995, McGovern \& Olney 1996). Subsequently, it was demonstrated that frequencies of favorable or unfavorable climate patterns control spring temperatures and precipitation, as well as the abundance and types of prey available to anadromous fish larvae and juveniles in Chesapeake Bay, including striped bass (Wood 2000, Kimmel \& Roman 2004). North \& Houde (2003) reported higher concentrations of fish larvae and zooplankton prey in the estuarine turbidity maximum (ETM), a convergence zone at the head of many coastal plain estuaries (Schubel 1968), in a wet year when the ETM feature was enhanced.

Our research was conducted in the upper Chesapeake Bay, in the region of the salt front and ETM (Sanford et al. 2001). In Chesapeake Bay and the St. Lawrence River, there is evidence of a link between the survival of anadromous fish larvae, e.g. striped bass Morone saxatilis and rainbow smelt Osmerus mordax, and the dynamics and structure of the ETM and salt front (Dodson et al. 1989, Sirois \& Dodson 2000a,b, North \& Houde 2003, 2006). In Chesapeake Bay, the ETM is a favorable nursery for striped bass and larvae of the congeneric white perch Morone americana (North \& Houde 2001, Shoji et al. 2005), possibly because high concentrations of the copepod Eurytemora affinis, a common prey of these larvae, are found in and near the ETM (Boynton et al. 1997, North \& Houde 2001, Roman et al. 2001).

Mechanisms that support strong striped bass recruitments in years characterized by wet, cool, spring conditions are still poorly understood. Here, we report on climatic and biophysical controls of recruitment variability, emphasizing temporal and spatial variability in processes controlling the inter-annual prey availability to striped bass larvae. Specifically, we analyzed the distribution of striped bass larvae in the upper Chesapeake Bay relative to environmental gradients and the spatial and temporal variability in zooplankton concentrations in years of contrasting hydrological conditions. Our analysis included new data on the distribution and feeding success of striped bass larvae for the years from 2001 to 2003; a retrospective analysis of larval and zooplankton data from 1996, 1998, and 1999; and a synthetic analysis on annual variability in the 
abundance and timing of zooplankton prey of striped bass larvae for the years from 1993 to 2002. Additionally, we developed a simple statistical model driven by freshwater flow and temperature that describes the level of YOY striped bass recruitment.

Our 4 objectives were to demonstrate how hydroclimate variability (1) controls the distribution of striped bass larvae in the upper Chesapeake Bay; (2) facilitates spatio-temporal overlap of larvae with mesozooplankton prey; (3) enhances or inhibits larval feeding success; and (4) contributes to variability in larval growth, survival, and year-class strength. The research addresses the broad question: 'Does availability of mesozooplankton prey control striped bass recruitment in the upper Chesapeake Bay?'

\section{MATERIALS AND METHODS}

Research surveys. Survey cruises in the upper Chesapeake Bay were conducted during April and May of 1996, 1998, 1999, and 2001 to 2003 (Fig. 1). Prior to ichthyoplankton sampling in each cruise, the location of the ETM and salt front were determined from a CTD survey by plotting salinity and turbidity profiles at $10 \mathrm{~km}$ intervals. The ETM's location and center were defined as the geographic range (typically
5 to $10 \mathrm{~km}$ ) and its mid-point location, respectively, of maximum turbidity. Sampling stations were selected to map ichthyoplankton abundance up-estuary, within, and down-estuary of the ETM and salt front (Fig. 1). A CTD cast to profile temperature, salinity, and turbidity preceded ichthyoplankton sampling at each station. Station depths ranged from 11 to $13 \mathrm{~m}$.

Ichthyoplankton was sampled with an openingclosing, $1 \mathrm{~m}^{2}$ Tucker trawl, with $280 \mu \mathrm{m}$ mesh, fished at 3 discrete depths in 2001 and 2002 and 2 depths in 2003 , to include the entire water column (Table 1). The volume of water filtered by a 2 min tow in each depth stratum was, on average, $126 \mathrm{~m}^{3}$. Samples were preserved in $95 \%$ ethanol. In the laboratory, striped bass

Table 1. Morone saxatilis. Number of Tucker-trawl samples, and mean (SD) concentrations (no. $\mathrm{m}^{-3}$ ) of striped bass eggs, yolk-sac larvae, and feeding-stage larvae in the upper Chesapeake Bay in 2001, 2002, and 2003

\begin{tabular}{|ccccc|}
\hline Year & $\begin{array}{c}\text { No. of } \\
\text { samples }\end{array}$ & Eggs & $\begin{array}{c}\text { Yolk-sac } \\
\text { larvae }\end{array}$ & $\begin{array}{c}\text { Feeding-stage } \\
\text { larvae }\end{array}$ \\
\hline 2001 & 130 & $0.84(1.38)$ & $0.05(0.09)$ & $0.02(0.05)$ \\
2002 & 126 & $0.68(2.23)$ & $0.03(0.06)$ & $1.50 \times 10^{-3}(0.01)$ \\
2003 & 65 & $0.05(0.11)$ & $0.90(1.67)$ & $3.70(6.93)$ \\
\hline
\end{tabular}

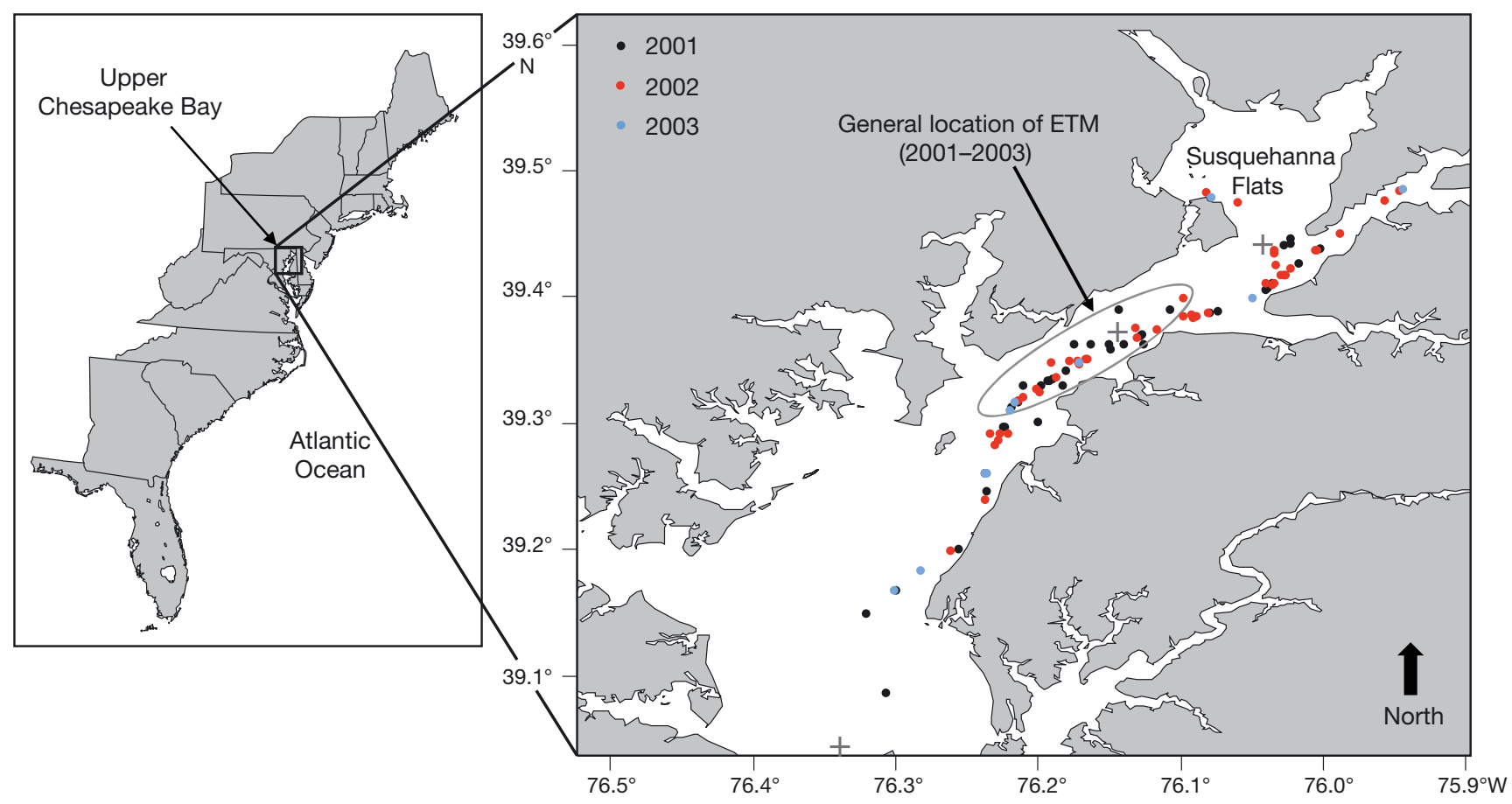

Fig. 1. Research area and ichthyoplankton and zooplankton sampling stations in Chesapeake Bay. Tucker-trawl sampling stations during May cruises are shown explicitly on the map for 2001 to 2003; station locations in other years were similar. (+) Mesozooplankton monitoring stations of the Chesapeake Bay Program (www.chesapeakebay.net) that were used in the present study (NB Stn $4.3 \mathrm{C}$ is located further down-estuary at $38.56^{\circ} \mathrm{N}, 76.43^{\circ} \mathrm{W}$ ). Ellipse demarcates the general location of the estuarine turbidity maximum (ETM) for the years 2001 to 2003 
Morone saxatilis eggs and larvae were identified, enumerated, and expressed as number per cubic meter. Mean concentrations of larvae among years were compared using the non-paramateric Kruskal-Wallis test, with pairwise multiple comparisons testing for significant $(p<0.05)$ differences with appropriate $p$-value adjustments.

Distributions of striped bass eggs and larvae were analyzed by pooling ichthyoplankton data from all surveys in each year to evaluate average annual distribution patterns. This analysis was motivated by knowledge of the strong positive relationship between the mean freshwater discharge in spring months and the year-class strength (Houde \& Secor 1996, North \& Houde 2001), which suggested that the effects of inter-annual variability in flow surpassed the effects of within-year, seasonal flow variability. Except for 1996, when sampling of eggs was insufficient, egg and larval concentrations were averaged in $5 \mathrm{~km}$ bins and standardized as $z$-scores (residual divided by standard deviation) to delineate stage-specific centers of abundance.

Zooplankton spatio-temporal distribution and overlap with larvae. Inter-annual and spatial variability in distributions of zooplankton were analyzed in the upper bay. Most analyses were on 2 dominant prey of striped bass larvae, the calanoid copepod Eurytemora afffinis and the cladoceran Bosmina longirostris (Beaven \& Mihursky 1980, Limburg et al. 1997, Campfield 2005). Additionally, spatial (1996, 1998, 1999, 2001 to 2003) and temporal (1993 to 2002) patterns in the combined concentrations of these taxa were analyzed and compared to minimum prey thresholds for striped bass larvae. Minimum prey thresholds were defined as prey concentrations below which sharp declines in larval striped bass survival and growth occurred in 3 laboratory studies. One study tested Artemia nauplii as prey (Eldridge et al. 1981), one tested Eurytemora affinis nauplii and other life stages
(Tsai 1991), and one used a natural assemblage of zooplankton (Chick \& Van Den Avyle 1999b). Local aggregations of zooplankton prey due to small-scale physical processes at spatial scales below the resolution of survey data analyzed here (1 to $10 \mathrm{~km}$ ) may enhance feeding success (MacKenzie et al. 1990). The prey thresholds we adopted are coarse, but conservative, minimum prey levels above which most larvae are expected to feed successfully.

Inter-annual trends in spring zooplankton along the channel axis in the upper bay were evaluated from samples taken at 4 monitoring stations by the Chesapeake Bay Program (CBP; CB-Program 2002) (Table 2). These stations were sampled approximately once in April and March and twice in May in all years. The CBP zooplankton monitoring was terminated in 2002; consequently, zooplankton analysis for 2003 was based on abundance estimated from high-frequency acoustics sampling (see below). Three of the four CBP stations (Fig. 1) were located within the primary striped bass nursery, and one (CB4.3C) was located 10 to $15 \mathrm{~km}$ down-estuary. The CBP zooplankton was sampled in duplicate, stepped-oblique tows, with paired $20 \mathrm{~cm}$ bongo nets (202 $\mu \mathrm{m}$ mesh). Eurytemora affinis copepodites and adults, immature and adult Bosmina longirostris, and the sum of these prey types were standardized to the number of individuals per cubic meter of water sampled.

In 2003, a Tracor acoustic profiling system (TAPS) provided estimates of zooplankton abundance and distribution. The TAPS was mounted on the CTD. TAPS records depth and acoustical volume back-scattering strength (Sv) at 6 transducer frequencies $(265,420$, 700, 1100, 1850, and $3000 \mathrm{kHz}$ ) (Holliday \& Pieper 1995). We analyzed TAPS zooplankton between 0.5 and $1.4 \mathrm{~mm}$, or the equivalent spherical radii (ESR) of from 0.06 to $0.25 \mathrm{~mm}$, which includes the size range of zooplankton eaten by striped bass larvae. TAPS pro-

Table 2. Data sources used for analyses of spatial and temporal mesozooplankton variability. The time periods for spatial analyses were selected to coincide with available ichthyoplankton survey data. Time periods for the temporal analyses represent the longest consecutive periods during which there were no major changes in sampling in the upper bay. Chesapeake Bay Program data are available at www.chesapeakebay.net/. TAPS: Tracor acoustic profiling system

\begin{tabular}{|c|c|c|c|}
\hline Data source & Temporal period & Spatial coverage & Sampling method \\
\hline $\begin{array}{l}\text { Spatial analyses } \\
\text { Chesapeake Bay Program } \\
\text { mesozooplankton monitoring } \\
\text { NSF BITMAX project }\end{array}$ & $\begin{array}{l}\text { April and May 1996, } \\
\text { 1998, 1999, 2001, 2002, } \\
\text { May 2003 }\end{array}$ & $\begin{array}{l}\text { Stns CB2.1, CB2.2, CB3.3C, } \\
\text { CB4.3C (see Fig. 1). } 50 \mathrm{~km} \text { at } \\
5-10 \mathrm{~km} \text { intervals (see Fig. 1) }\end{array}$ & $\begin{array}{l}\text { Bongo net oblique tows } \\
(202 \mu \mathrm{m} \text { mesh). Multifrequency } \\
\text { acoustic backscatter, TAPS }\end{array}$ \\
\hline $\begin{array}{l}\text { Temporal analyses } \\
\text { Chesapeake Bay Program } \\
\text { mesozooplankton monitoring }\end{array}$ & $\begin{array}{l}\text { All stations sampled once } \\
\text { monthly March-May } \\
\text { 1993-2002; Stns CB2.1 } \\
\text { and CB2.2 sampled twice } \\
\text { each May 1993-2001 }\end{array}$ & $\begin{array}{l}\text { Stns CB2.1, CB2.2, CB3.3C } \\
\text { (see Fig. 1) }\end{array}$ & $\begin{array}{l}\text { Bongo net oblique tows } \\
\text { (202 } \mu \mathrm{m} \text { mesh) }\end{array}$ \\
\hline
\end{tabular}


vided estimates of the total prey concentration in the water column (usually $\sim 13 \mathrm{~m}$ depth). The estimates of total prey in the designated size range mostly represented Eurytemora affinis and Bosmina longirostris, based on their numerical dominance in plankton tows from other years.

To evaluate inter-annual and spatial variability in Eurytemora affinis and Bosmina longirostris, concentration data were fit with a loess smoothing function (span $=0.7$, degree $=1)$. We report mean zooplankton concentrations, based on the loess fits and standard errors of the fits. The loess fits helped to define trends and patterns, as well as their conspicuous peaks in some years.

Loess fits $(\operatorname{span}=0.7$, degree $=1$ ) of larval striped bass concentrations by distance down-estuary $(\mathrm{km})$ were compared for overlap with zooplankton. For each year, the degree of spatial overlap was evaluated by comparing locations of maximum concentrations of zooplankton and larvae between years. Additionally, mean annual concentrations of zooplankton were calculated for (1) the entire upper bay, (2) the area where striped bass larvae occurred, and (3) the area of maximum larval concentrations. Correlation statistics were derived between mean zooplankton concentration in each of the 3 designated areas during the period of peak production of larval-stage striped bass (April to May) and an age-0 striped bass recruitment index (mean number of YOY striped bass per seine haul in the Maryland Department of Natural Resources seine survey) (Durell \& Weedon 2009) to evaluate the relationship between zooplankton prey availability and recruitment success.

The timing of the spring zooplankton peak, based on CBP zooplankton monitoring, and its possible relationship to striped bass recruitment were also evaluated. For this analysis, mean concentrations of Eurytemora affinis and Bosmina longirostris, and their summed mean concentration in the striped bass nursery area (Table 3), were examined by ordinal day (from March to June) to evaluate inter-annual differences in seasonality.

Diet analyses. Diet analysis was conducted on striped bass larvae from collections taken between 2001 and 2003. Standard lengths (SL) of larvae that ranged from 4.0 to $10.5 \mathrm{~mm}$ were measured to the nearest $0.1 \mathrm{~mm}$. Gut contents $(\mathrm{n}=193)$ were removed under a dissecting microscope, identified, and measured with an ocular micrometer. In samples with 5 or fewer larvae, gut contents of all larvae were analyzed. In samples with $>5$ larvae, from 5 to 10 individuals were selected randomly for stomach analysis.

Location and environmental effects on feeding success of larvae were evaluated. Binomial and Poisson regression were applied to test for differences in the percentage of larvae with prey in their gut and the mean number of prey items per gut, respectively. Analysis of covariance (ANCOVA) was applied to compare feeding success among years using larval length as the covariate. At $7.5 \mathrm{~mm} \mathrm{SL}$, the yolk sac is fully absorbed and teeth are easily visible, indicating obligate external feeding by this size and ontogenetic stage (Mansueti 1958). Accordingly, larvae were separated into 2 size classes, $<7.5$ and $\geq 7.5 \mathrm{~mm}$. For each length class, regression analyses were used to evaluate the effects of salinity, turbidity, and distance down-estuary on mean number of prey items per gut. Significance levels were adjusted for multiple comparisons using Bonferroni's correction, by multiplying the accepted level of significance $(p<0.05)$ by $1 / n$, where $n$ is the number of comparisons.

Recruitment model. A multiple regression model was developed to describe and forecast recruitment of age-0 juvenile striped bass. Spring freshwater flow and temperature were included in the model, because

Table 3. Eurytemora affinis and Bosmina longirostris. Mesozooplankton prey concentrations in the upper Chesapeake Bay for years of low, average, and strong striped bass Morone saxatilis young-of-the-year recruitment. Data represent mean concentrations $\left(\right.$ no. $\mathrm{m}^{-3}$ ) at (1) all upper bay stations sampled for striped bass larvae, (2) stations where larvae occurred, and (3) locations where peak concentrations of larvae occurred from mid-April through May in dry years (1999 and 2002), a normal freshwater-discharge

year (2001), and wet years (1996, 1998, and 2003). NA: not available, i.e. no feeding-stage striped bass larvae were collected

\begin{tabular}{|c|c|c|c|}
\hline Year & $\begin{array}{c}\text { All upper } \\
\text { bay stations sampled }\end{array}$ & $\begin{array}{c}\text { Stations of } \\
\text { overlapping occurrence }\end{array}$ & $\begin{array}{c}\text { Stations of } \\
\text { peak larval abundance }\end{array}$ \\
\hline \multicolumn{4}{|c|}{ Low recruitment } \\
\hline 1999 & 1672 & NA & NA \\
\hline 2002 & 531 & 606 & 1935 \\
\hline \multicolumn{4}{|c|}{ Average recruitment } \\
\hline 1998 & 1299 & 1090 & 1802 \\
\hline 2001 & 7422 & 2296 & 275 \\
\hline \multicolumn{4}{|c|}{ Strong recruitment } \\
\hline 1996 & 7416 & 14404 & 269263 \\
\hline 2003 & 22873 & 15877 & 286160 \\
\hline
\end{tabular}


spring freshwater flow controls the abundance of zooplankton prey (Kimmel et al. 2006) and temperature is an important controller of zooplankton post-embryonic development (Devreker et al. 2006) and striped bass spawning, growth, and larval survival (Rutherford \& Houde 1995, Secor \& Houde 1995). The model was fit to the recruitment time series for the years from 1985 to 2006 and then run to forecast recruitments for the years from 2007 to 2009 . We evaluated model performance with and without zooplankton concentration as an independent variable for the years from 1985 to 2002 when mesozooplankton monitoring data were available (CB-Program 2002). Akaike's information criterion (Akaike 1974) was used to evaluate goodness-of-fit between models with and without zooplankton included.

\section{RESULTS}

\section{Abundance of larvae and freshwater flow}

Freshwater discharge into the upper Chesapeake Bay during spring (March and April) varied $>2$-fold during the 6 years included in this research (Fig. 2); with highest mean flows in 1996, 1998, and 2003; lowest flows in 1999 and 2002; and moderate flows in 2001. Concentrations of feeding-stage striped bass Morone saxatilis larvae were significantly different among years (Kruskal-Wallis, $\mathrm{df}=5, \mathrm{p}<2.2 \times 10^{-16}$ ). Concentrations of larvae were significantly $(\mathrm{p}<0.05)$ higher in $2003\left(\right.$ mean $\left.=3.7 \mathrm{~m}^{-3}\right), 1996\left(\right.$ mean $\left.=2.5 \mathrm{~m}^{-3}\right)$, and 1998 (mean $=0.1 \mathrm{~m}^{-3}$ ), when hydrological conditions were very wet, and when recruitment levels were exceptionally high (1996 and 2003) and moderate (1998). Concentrations of feeding-stage larvae were significantly $(\mathrm{p}<0.05)$ lower in $1999\left(\right.$ mean $\left.=0 \mathrm{~m}^{-3}\right)$ and 2002 (mean $=0.0015), 2$ very dry years that experienced poor YOY recruitment.

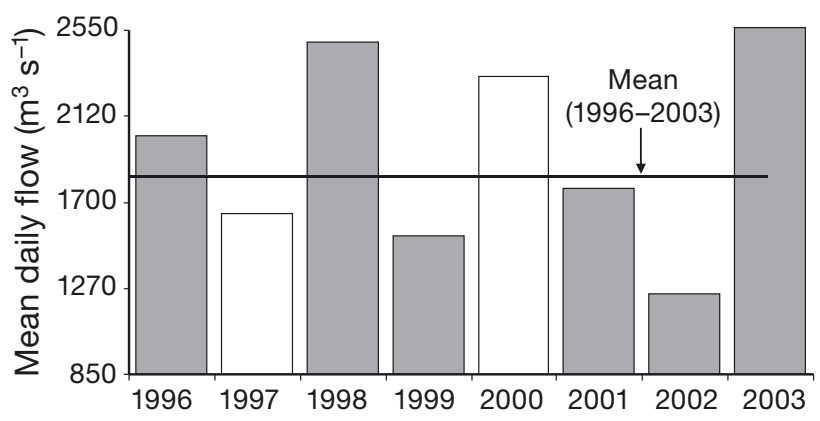

Fig. 2. Mean daily Susquehanna River discharge during March and April for the years 1996 through 2003 at the Conowingo Dam (US Geological Survey, http://water.usgs.gov/nsip). Shaded bars indicate years considered in the present study

\section{Responses of egg and larval distributions to hydrological variability}

Striped bass egg distributions were similar in the 5 years examined (i.e. excluding 1996, for which egg samples were insufficient for analysis) and were not associated with the ETM or salt front. Observed differences in egg distributions between wet and dry years did suggest that variability in hydrological conditions may have influenced locations where eggs occurred (Fig. 3). Eggs were patchily distributed and occurred over a relatively broad range $(>25 \mathrm{~km})$ in the upper bay, which extended down-estuary into the ETM and salt front in all years except 2003, the wettest year in our series (Fig. 3). Comparatively, egg abundance in 2003 was higher up-estuary and better defined spatially than in other years.

The distribution of yolk-sac and feeding-stage larvae of striped bass differed among the 5 years (Fig. 3), in response to inter-annual differences in March/April freshwater flow and associated hydrographic conditions (Fig. 2). In general, in years of high freshwater discharge (1998 and 2003) larvae were located further down-estuary and were more associated with the salt front and ETM (Fig. 3). In contrast, during years of low freshwater discharge (2002), yolk-sac and feedingstage larvae were most abundant up-estuary and less associated with the ETM. However, some yolk-sac larvae did occur at moderately high salinities (3 to 5) within the ETM in the dry year of 2002 (Fig. 3). In the other dry year (1999), yolk-sac larvae occurred far upestuary and no feeding-stage larvae were collected. There was a positive, although not significant, relationship between freshwater flow and the distance down-estuary, where peak concentrations of larvae occur $(r=+0.60, p=0.27)$, and a negative relationship between freshwater flow and the distance between the location of peak larval concentrations and the salt front and ETM $(r=-0.62, p=0.25)$. The relationships between locations of larval occurrence and freshwater discharge were not significant at the $\mathrm{p}=0.05$ level, although this outcome probably occurred because only 5 years of data were available for this analysis.

\section{Diet and feeding success}

Striped bass larvae fed almost exclusively on the cladoceran Bosmina longirostris and the calanoid copepod Eurytemora affinis. All other prey taxa, including the cladocera Daphnia spp., the calanoid copepod Acartia tonsa, and the cyclopoid copepod Oithona sp., were uncommon and occurred in $<5 \%$ of larval guts. Feeding success was higher in 2003 (2.0 prey larva ${ }^{-1}$ ) than in 2001 (0.8 prey larva ${ }^{-1}$ ), based on 

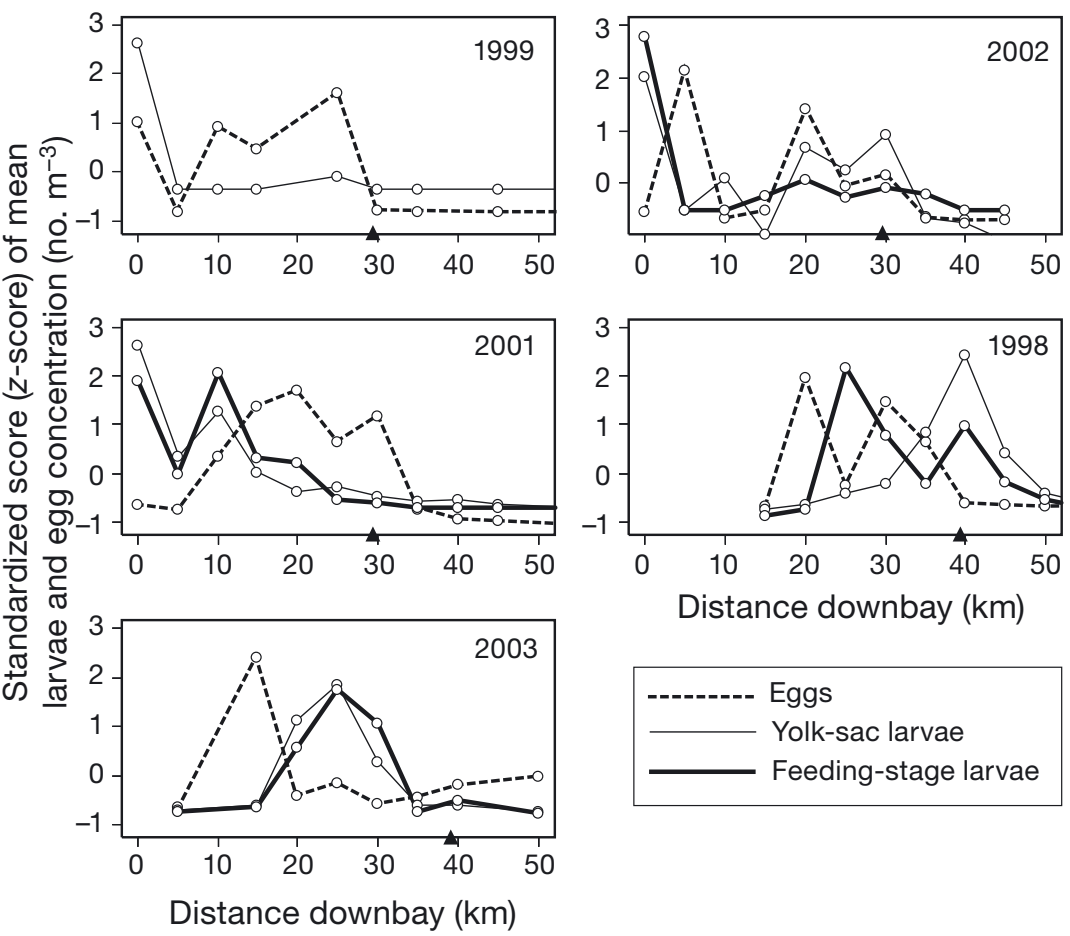

Fig. 3. Morone saxatilis. Inter-annual variability in the average distribution of striped bass eggs and larvae along the main axis of the upper Chesapeake Bay during April and May in 2 dry years (1999 and 2002), an average freshwater discharge year (2001), and 2 wet years (1998 and 2003). ETM mid-point is indicated by a triangle on the $x$-axis

both number of prey per larva $\left(\mathrm{p}=2.2 \times 10^{-12}, \mathrm{df}=189\right)$ and prey incidence in guts $\left(\mathrm{p}=4.6 \times 10^{-6}, \mathrm{df}=189\right)$. In 2002, there were too few $(n=2)$ feeding-stage larvae available to analyze feeding success.

The most notable difference in diet between years was the greater importance of Bosmina longirostris in 2003, the year of high freshwater discharge. The incidence of $B$. longirostris in the guts of larvae increased from $<22 \%$ in 2001 ( $\mathrm{n}=102$ ) to $50 \%$ in 2003 ( $\mathrm{n}=89$ ). The number of $B$. longirostris consumed per larva in 2003 was also higher than in 2001 ( $\mathrm{p}=4.7 \times 10^{-11}$, df = 189). Feeding on Eurytemora affinis did not differ between years.

For the combined years, the number of prey in guts $\left(\mathrm{p}=9.1 \times 10^{-9}, \mathrm{df}=189\right)$ and the percentage of larvae with prey present in their guts $(\mathrm{p}=2.8 \times$ $10^{-6}$, df $=189$ ) were directly related to larval size. For individual years, the relationship was significant in $2001\left(\mathrm{p}=3.6 \times 10^{-8}, \mathrm{df}=100\right)$, but not in 2003, when numbers of prey per gut were variable, but relatively high for larvae of all lengths (Fig. 4). In 2001, results indicated that small (<7.5 mm), first-feeding larvae fed less successfully than larger larvae, and, importantly, firstfeeding larvae in 2001 fed less successfully than in 2003.
In 2001, abiotic factors that we measured had no detectable effect on feeding success of small $(<7.5 \mathrm{~mm})$ or large ( $\geq 7.5 \mathrm{~mm}$ ) striped bass larvae. However, in 2003, feeding success of small and large larvae was related to abiotic factors. For small larvae in 2003, feeding on the cladoceran Bosmina longirostris was higher up-estuary $\left(\mathrm{p}=6.5 \times 10^{-5}, \mathrm{df}=32\right)$ and at lower turbidities $\left(\mathrm{p}=9.2 \times 10^{-3}\right.$, $\mathrm{df}=32$ ). Similarly, feeding on $B$. longirostris by large larvae in 2003 was higher up-estuary $\left(\mathrm{p}=2.9 \times 10^{-7}\right.$, df $\left.=40\right)$, at lower salinities $(p=0.01$, $d f=40)$, and at lower turbidities $(\mathrm{p}=0.02, \mathrm{df}=40)$. Large larvae in 2003 fed more successfully on the copepod Eurytemora affinis at downestuary stations $\left(\mathrm{p}=5.3 \times 10^{-4}, \mathrm{df}=40\right)$, at higher salinities $(\mathrm{p}=0.01, \mathrm{df}=40)$.

\section{Overlap of striped bass larvae and zooplankton prey: relationship to YOY recruitment}

The distribution of zooplankton serving as prey for larval striped bass is controlled by hydrological conditions. Maximum concentrations of the combined, dominant, upper bay mesozooplankters Eurytemora affinis and Bosmina longirostris were located further down-estuary $(\mathrm{p}<0.01)$ in years of high freshwater discharge. In dry years, concentrations of E. affinis were higher at up-estuary locations (e.g. 1999 and 2002), while in years of high freshwater discharge (1996 and 1998) E. affinis peaked down-estuary, at or

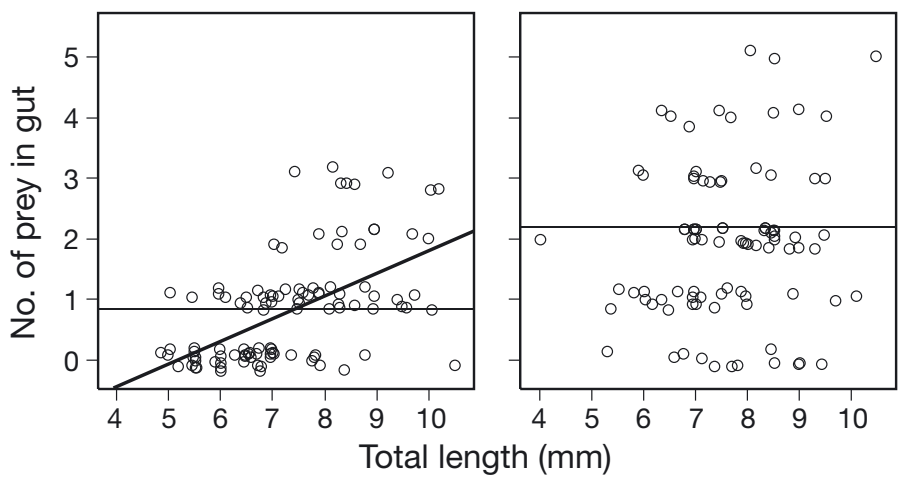

Fig. 4. Morone saxatilis. Relationship between feeding success and length of striped bass larvae in the upper Chesapeake Bay based on the number of prey items in larval guts in (a) 2001 and (b) 2003. The regression line for the significant relationship in 2001 is shown; the relationship in 2003 was not significant. Horizontal lines in each plot indicate the mean feeding success, i.e. number of prey per larva, for each year 
below the salt front and ETM (Fig. 5). B. longirostris occurred in highest concentrations up-estuary of the salt front and ETM in all years. Still, in years of moderate and high freshwater discharge, its distribution shifted down-estuary, coinciding to a greater degree with the ETM (Fig. 5).

The effect of hydrological variability on zooplankton distribution and abundance apparently served to control availability of prey for larvae (Table 3). During the dry years of 1999 and 2002, combined concentrations of Eurytemora affinis and Bosmina longirostris were almost always below the threshold levels required for production of striped bass larvae (ca. 50000 prey $\mathrm{m}^{-3}$ ) at all locations in the upper bay (Fig. 6). In 1999 and 2002, recruitment index values of YOY striped bass in the Maryland Department of Natural Resources seine survey were 1.9 and 1.4 ind. haul $^{-1}$, respectively, and were well below the longterm mean of 5.5 ind. haul ${ }^{-1}$.

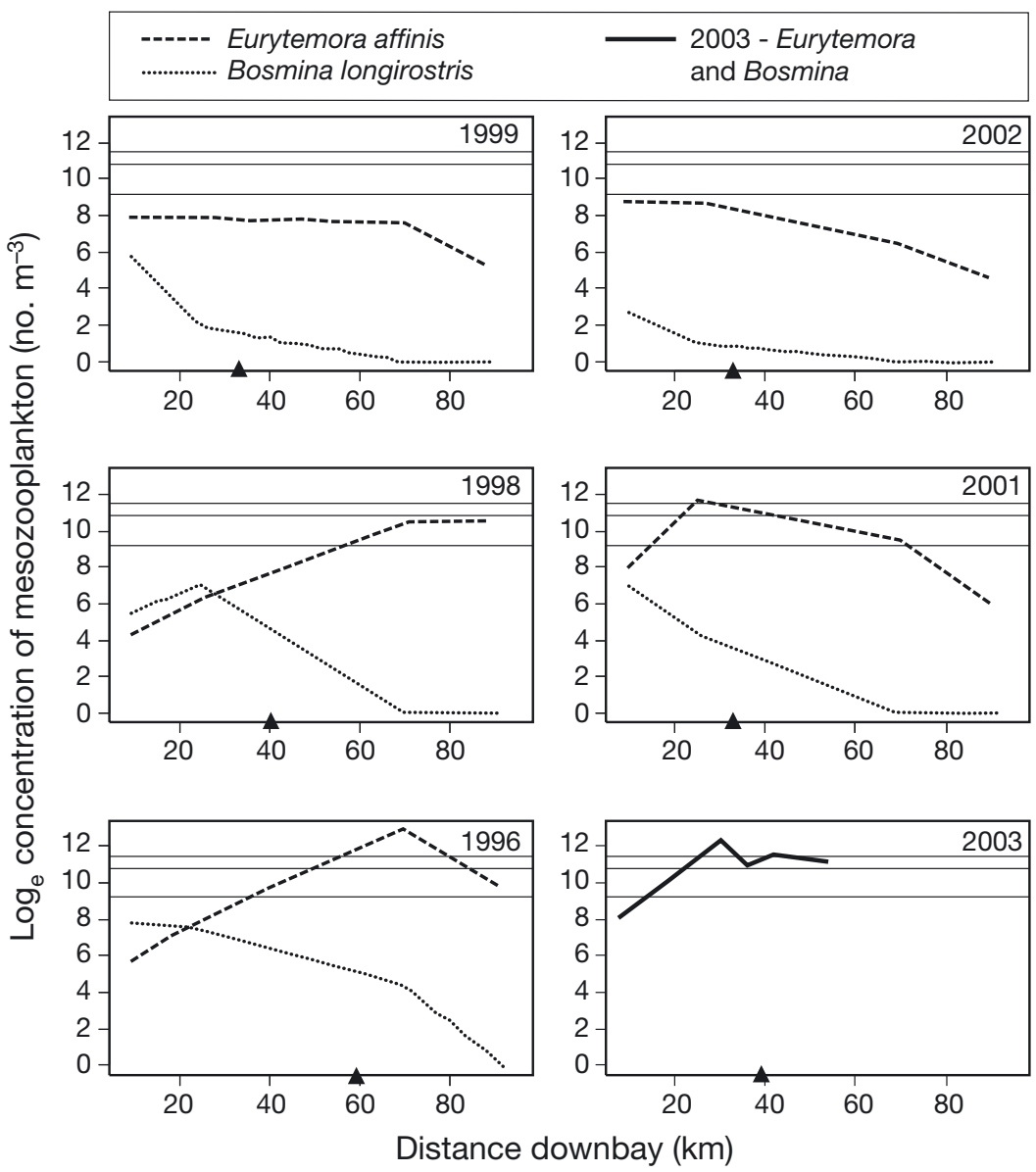

Fig. 5. Spatial distribution of the calanoid copepod Eurytemora affinis and the cladoceran Bosmina longirostris in the upper Chesapeake Bay during April and May, when spring freshwater flows were low (1999 and 2002), average (2001), and above average (1996, 1998, and 2003). Horizontal lines depict 3 different estimates (Eldridge et al. 1981, Tsai 1991, Chick \& Van Den Avyle 1999b) of minimum required prey levels for favorable survival and growth of striped bass Morone saxatilis larvae. ETM mid-point is indicated by a triangle on the $x$-axis
In 1998 and 2001, when freshwater discharges during March and April were high and near average, respectively, zooplankton concentrations were at moderate levels (Fig. 6) and YOY recruitments of striped bass were moderate $\left(4.3\right.$ and 7.2 ind. haul ${ }^{-1}$, respectively). Zooplankton concentrations reached the minimal prey threshold of 50000 prey $^{-3}$ at some upper bay locations in 1998 and 2001, but most striped bass larvae were located up-estuary of the sites with peak prey concentrations and did not experience favorable feeding conditions (Fig. 6).

In 1996 and 2003, 2 wet, high-discharge years, zooplankton concentrations were notably higher throughout the upper bay (Table 3, Fig. 6). YOY striped bass recruitment indices were also high (15.0 and 11.9 ind. haul $^{-1}$, respectively). In 1996 and 2003, zooplankton concentrations were far above the threshold prey level (50000 prey $\mathrm{m}^{-3}$ ) at locations supporting the highest concentrations of striped bass larvae and often were above the threshold level at all locations where larvae occurred (Table 3, Fig. 6). Near the ETM, zooplankton concentrations exceeded 100000 prey $\mathrm{m}^{-3}$. Most importantly, there was high spatial overlap of zooplankton and striped bass larvae in 1996 and 2003 (Fig. 6).

Considering only locations where larval striped bass occurred, the correlation between spring zooplankton concentration and YOY recruitment indices for July through September was significant $\left(p<0.05, r^{2}>0.74\right)$. Considering all sites sampled for striped bass larvae, correlations between mean spring zooplankton concentrations and YOY striped bass recruitment indices were positive, but not significant (Table 4).

There was substantial temporal variability in occurrence of dominant zooplankton, with probable consequences for synchrony between production of striped bass larvae and prey. The seasonality of Eurytemora affinis differed strongly among years (Fig. 7). Its concentrations usually peaked before May and declined thereafter. Bosmina longirostris concentrations and seasonality differed less among years. A B. longirostris bloom commenced between late April and early May, and it usually peaked in early June or at dates after our surveys had been terminated.

Feeding conditions for striped bass larvae, judged by temporal overlap with zooplankton, vary inter-annually 

of striped bass Morone saxatilis feeding-stage larvae and the combined concentration of Bosmina longirostris and Eurytemora affinis zooplankton in the upper Chesapeake Bay, when spring freshwater flows were low (1999 and 2002), average (2001), and above average (1996, 1998, and 2003). Loess curves were fit to concentrations of zooplankton (open symbols and dashed lines; dotted lines are standard errors) and percentage of larvae (thick pict 3 estimates of minimum required prey levels (cf. Fig. 5 legend) for favorable survival and growth of striped bass larvae. ETM mid-point is indicated by a triangle on the $x$-axis
Fig. 6. Spatial match-mismatch solid lines). Horizontal lines de-

\footnotetext{
ธี

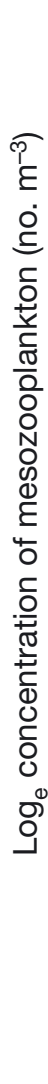

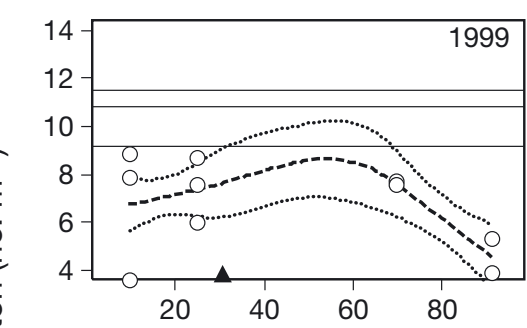

(Fig. 7). Peak concentrations of larvae occur from late April through mid-late May (ordinal days 110 to 140) in the upper Chesapeake Bay. There is a strong relationship between the YOY recruitment index and the date of peak zooplankton concentration $\left(\mathrm{p}<0.01, \mathrm{r}^{2}=0.72\right)$ (Fig. 8). Aggregate zooplankton concentrations peaked within the 110 to 140 d interval in 4 years $(1993,1994$, 1996, and 2001) during the period from 1993 to 2002 (Fig. 8). In most years, zooplankton concentrations peaked earlier, before the third week of April, and then quickly declined. In those years, age-0 recruitment levels of
Table 4. Regression analysis between age-0 juvenile striped bass Morone saxatilis recruitment (geometric mean number per seine haul; Maryland Department of Natural Resources seine survey) and spring concentrations of mesozooplankon prey (Eurytemora affinis, Bosmina striped bass larvae, (2) stations where larvae occurred, and (3) locations where peak concentrations of larvae occurred. The analysis period indata were unavailable. Significant relationships are indicated in bold

\begin{tabular}{|lccc|}
\hline & Slope coefficient & Adj. R & $\mathrm{p}$ \\
\hline All upper bay stations sampled & $5.0 \times 10^{-4}$ & 0.34 & 0.13 \\
Stations of overlapping occurrence & $\mathbf{7 . 0} \times \mathbf{1 0}^{-4}$ & $\mathbf{0 . 7 9}$ & $\mathbf{0 . 0 3}$ \\
Station of peak larval abundance & $\mathbf{3 . 0} \times \mathbf{1 0}^{-5}$ & $\mathbf{0 . 7 4}$ & $\mathbf{0 . 0 4}$ \\
\hline
\end{tabular}
longirostris; no. $\mathrm{m}^{-3}$ ) including (1) all upper bay stations sampled for cluded the years 1996 through 2003, excluding 1997 and 2000, when

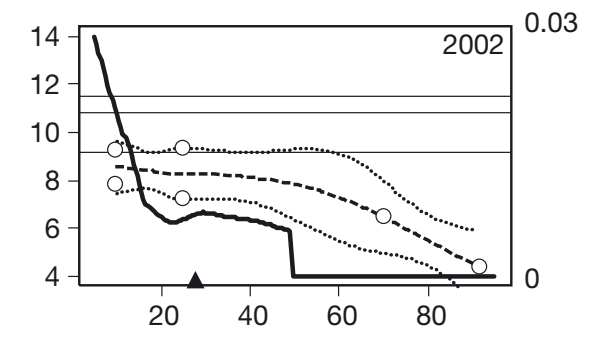

0.03

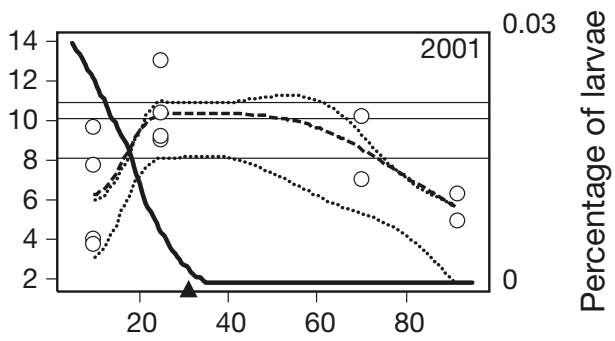

0.10

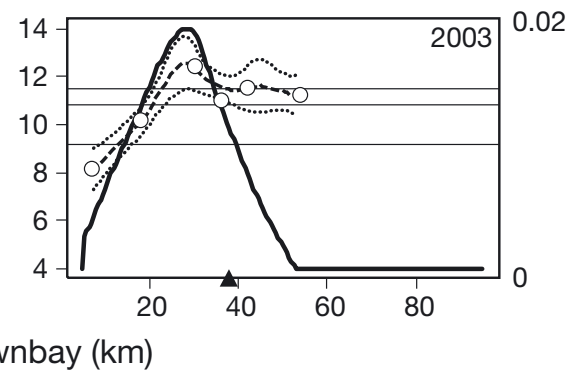

striped bass were generally low (Fig. 8). The notable late-season peaks in spring zooplankton concentrations in 1993 and 1996 were associated with the highest recruitment levels. The degree of temporal overlap and synchrony between combined zooplankton concentrations and striped bass larvae were driven mostly by variability in the seasonality of Eurytemora affinis. The overlap was enhanced when $E$. affinis peaked during May rather than in March or April, or when high concentrations of E. affinis persisted in May (Fig. 7).

\section{Recruitment model}

Based on evaluating a suite of abiotic and biotic variables, a multiple regression model for the years from 1985 to 2006 was developed that successfully described recruitment levels of YOY striped bass at 4 mo of age. The evaluation of potential independent variables indicated that only spring freshwater flow $(\mathrm{p}=1.4$ $\left.\times 10^{-4}\right)$ and spring temperature $(p=0.01)$ were significant in the model. The model described recruitment variability reasonably well $\left(\mathrm{R}^{2}=\right.$ 0.65). It also successfully forecasted YOY recruitment levels for 2007 and 2009, but was not successful for 2008 (Fig. 9). 

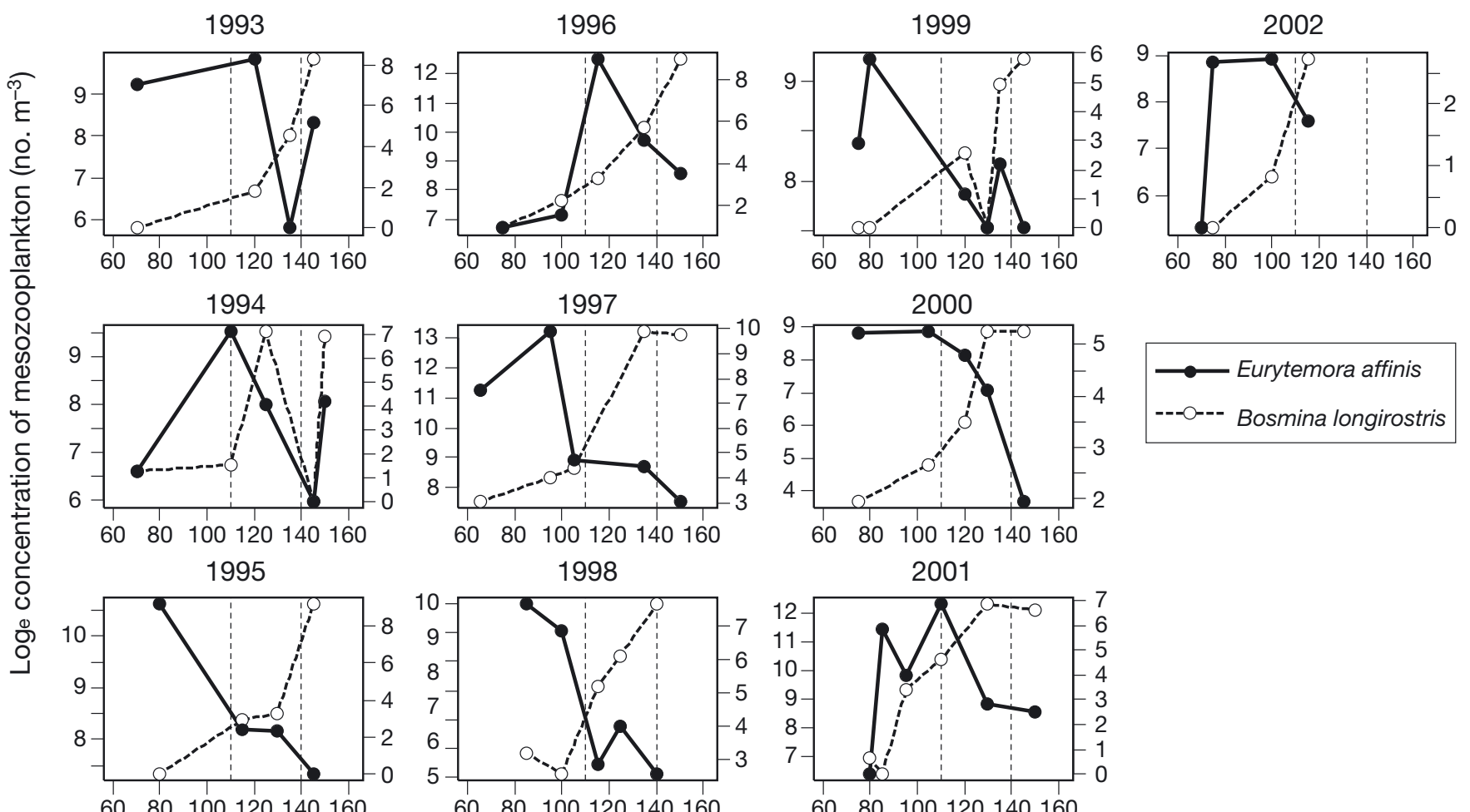

6080100120140160
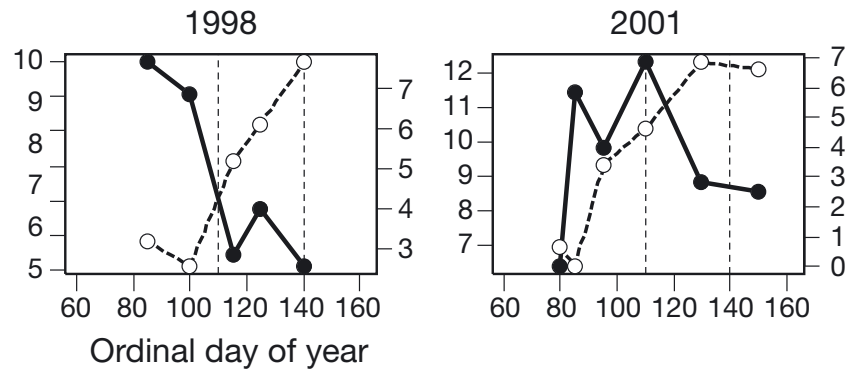

Fig. 7. Temporal patterns in occurrence of the dominant mesozooplankton (Eurytemora affinis, left y-axis; Bosmina longirostris, right $y$-axis) prey of striped bass Morone saxatilis larvae in the upper Chesapeake Bay. Data represent mean concentrations $\left(\log _{\mathrm{e}}\right.$ no. $\left.\mathrm{m}^{-3}\right)$ of mesozooplankton pooled for 3 Chesapeake Bay Program monitoring stations on the ordinal days indicated. Dashed vertical lines define the average period when most striped bass larvae occurred in the upper Chesapeake Bay, based on ichthyoplankton surveys

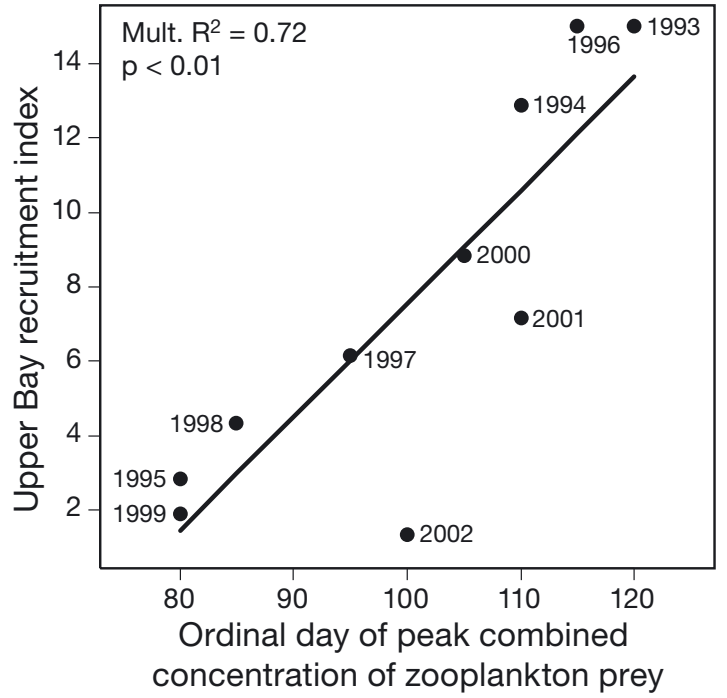

Fig. 8. Temporal match-mismatch of the striped bass Morone saxatilis young-of-the-year recruitment index calculated as a geometric mean catch per seine haul (Maryland Department of Natural Resources recruitment seine survey, www.dnr. state.md.us/fisheries/juvindex/index.html) and the ordinal day of peak prey (Eurytemora affinis, Bosmina longirostris) concentrations for striped bass larvae

\section{DISCUSSION}

\section{Environment, prey availability, and recruitment}

In Chesapeake Bay, recruitment of striped bass Morone saxatilis is controlled by both direct and indirect effects of hydrological variability on egg and larval survival. Indirect effects, driven by trophodynamics, distinguish years when recruitments are moderate (e.g. 1998 and 2001) and strong (e.g. 1996 and 2003). Direct effects (e.g. reduced retention of eggs and larvae, possible osmotic stress) and indirect trophodynamic effects are implicated during dry years (e.g. 1999 and 2002) when recruitments are poor, and when abundances of feeding-stage larvae are very low.

Direct effects of hydrological variability in 2 dry years (1999 and 2002) resulted in poor survival of prefeeding larvae and low abundances of feeding-stage larvae, most of which were located $>15 \mathrm{~km}$ up-estuary of the salt front and ETM. The low numbers of feedingstage larvae at the salt front and ETM in these years could have been attributable to an up-estuary shift in location of adult spawning in dry years. Alternatively, 


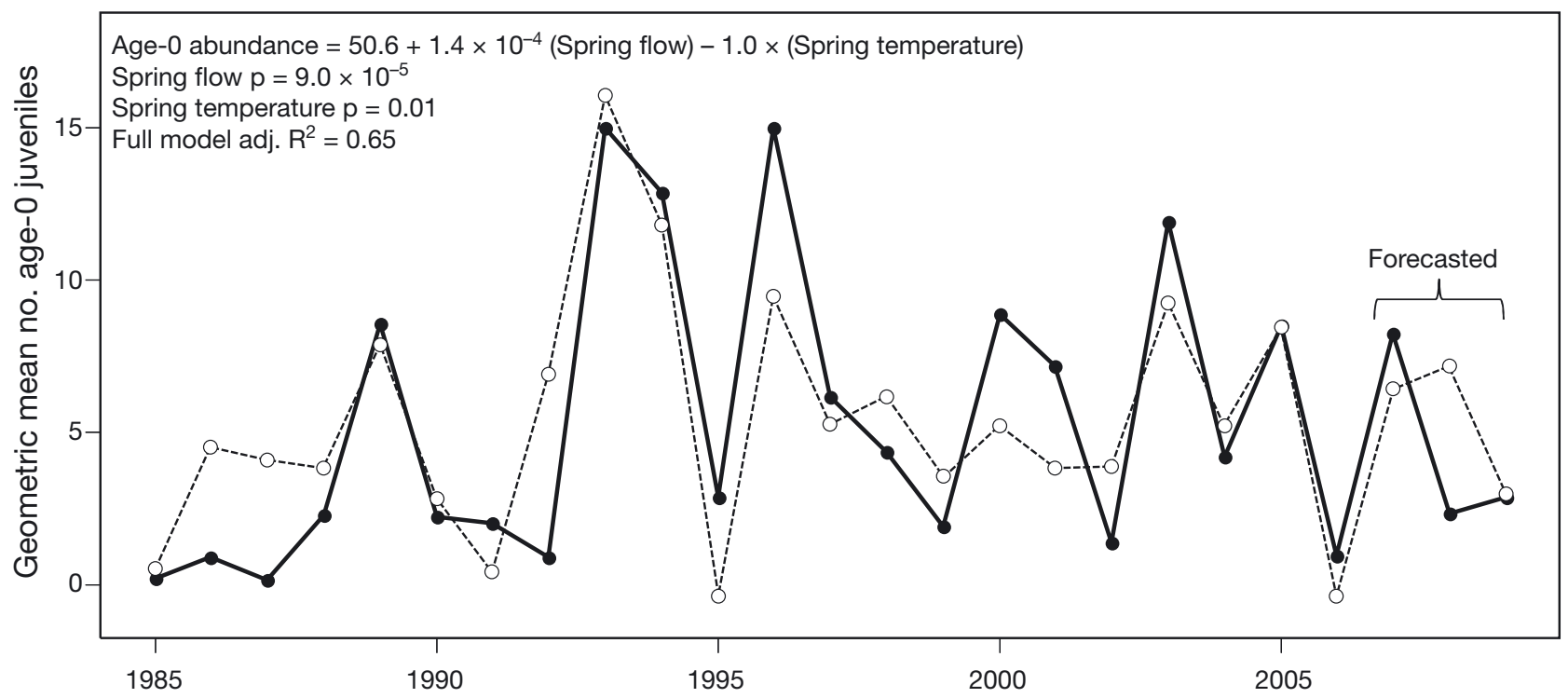

Fig. 9. Morone saxatilis. Observed, predicted, and forecasted recruitment of age-0 juvenile striped bass in the upper Chesapeake Bay. The solid line is age-0 abundance from the Maryland Department of Natural Resources recruitment seine survey (www.dnr.state.md.us/fisheries/juvindex/index.html). The model to predict recruitment includes Susquehanna River discharge for March through May from the US Geological Survey and air temperatures for March through May from Baltimore-Washington International Airport. The dashed line is modeled age-0 abundance for 1985 through 2006 and forecasted abundance for the 3 most recent years (2007 to 2009)

reduced capacity for retention and increased salinities near the ETM and salt front in dry years are a probable cause of down-estuary loss of eggs and larvae and, thus, of poor survival. This mechanism was proposed to explain the paucity of feeding-stage larvae in 1999 (North \& Houde 2001).

Our analysis highlighted how indirect effects of trophodynamics, including spatial and temporal matches and mismatches in occurrences of striped bass larvae and their zooplankton prey, are governed by temperature and hydrological variability before and during the season of egg and larval production. Enhanced spatiotemporal availability of zooplankton prey promotes larval feeding success and also faster growth (Martino 2008) and is associated with higher larval-stage survival. Results reported here indicate that (1) feeding success of striped bass larvae is enhanced in wet, strong recruitment years; (2) larvae and zooplankton prey occur further down-estuary and are more associated with the ETM and salt front in wet, strong recruitment years; and (3) the strongest recruitments occur when spring-season peaks in zooplankton prey occur in May rather than earlier in the year.

Both temporal and spatial matches of prey availability and striped bass larvae are necessary to produce the strongest recruitments. In 1996 and 2003, larvae were at their highest concentrations in the ETM region, where zooplankton prey exceeded 250000 prey $\mathrm{m}^{-3}$, levels far above the reported threshold prey levels for striped bass larvae that range from 50000 to 100000 prey $\mathrm{m}^{-3}$ (Eldridge et al. 1981, Chesney 1989, Tsai 1991). In contrast, in poor recruitment years, such as 1999 and 2002, mean prey concentrations were approximately 2 orders of magnitude lower (average: $<2000$ prey $\mathrm{m}^{-3}$ ) throughout the upper bay. In years of low or moderate freshwater flow that have strong temporal overlap between production of striped bass larvae and prey, suitable prey levels can occur at some locations in the upper bay, but generally not where most larvae occur. For example, in 2001, there was a spatial mismatch between striped bass larvae and prey (Fig. 6) that may explain the unexpectedly low recruitment despite a strong temporal match (Fig. 8). In contrast, during the high freshwater-flow year of 1998, larvae and zooplankton tended to co-occur in the ETM, but there was little temporal overlap between peaks in zooplankton concentrations and larval abundance. Similarly, Rutherford et al. (1997) suggested that high and low recruitment years in 1989 and 1988, respectively, had partly resulted from temporal matches and mismatches of prey with striped bass larvae in the upper bay. Although prey matches and mismatches were recognized, Rutherford et al. (1997) believed that the direct effects of temperature on larval growth and survival were of greater importance in those years.

Past research in Chesapeake Bay had identified temperature as a primary factor governing the growth of striped bass larvae (Rutherford \& Houde 1995, Secor \& 
Houde 1995). While temperature was important in the period from 2001 to 2003, it is probable that interannual variability in feeding success and growth were largely driven by inter-annual variability in prey availability. A regression relationship describing larval striped bass growth with respect to temperature (Rutherford \& Houde 1995) predicted higher growth in $2001\left(0.26 \mathrm{~mm} \mathrm{~d}^{-1}\right.$ at $\left.17.5^{\circ} \mathrm{C}\right)$ than in $2003\left(0.22 \mathrm{~mm} \mathrm{~d}^{-1}\right.$ at $\left.15.5^{\circ} \mathrm{C}\right)$. However, observed growth rates of small larvae $(<12 \mathrm{~d}$ old) did not differ in these 2 years, and the growth of larger larvae was faster in 2003 (Martino 2008), demonstrating the benefits of enhanced prey availability in this cool year.

\section{Spatial and inter-annual differences in diet composition}

Larvae fed more successfully in 2003 than in 2001 and 2002. In 2003, hydrological conditions were very wet and peak concentrations of larvae were within and just up-estuary of the ETM and salt front where Bosmina longirostris and Eurytemora affinis were abundant. Higher concentrations and strong seasonal variability in the abundance of E. affinis suggest that it is a more critical prey resource than $B$. longirostris for striped bass larvae in the upper Chesapeake Bay.

Concentrations of Bosmina longirostris rarely exceeded 8000 ind. $\mathrm{m}^{-3}$ in the upper Chesapeake Bay. However, this cladoceran enhances feeding success by larvae where it overlaps spatially during strong recruitment years. In 2003, when recruitment was high, $50 \%$ of striped bass larvae had eaten $B$. longirostris compared to $21 \%$ in 2001 when recruitment was lower. Feeding on B. longirostris was enhanced in freshwater, up-estuary of the ETM and salt front. In contrast, feeding on Eurytemora affinis was enhanced further down-estuary at higher salinities. Campfield (2004) also reported higher consumption of B. longirostris by striped bass larvae up-river of the salt front and ETM in the Patuxent River, while larvae downriver consumed mostly E. affinis. In the Hudson River, Bosmina freyi was the dominant food of larvae near the freshwater-salt water interface, where concentrations exceeded 100000 prey $\mathrm{m}^{-3}$ (Limburg et al. 1997).

\section{Seasonal timing of zooplankton and recruitment strength}

In the upper Chesapeake Bay, zooplankton concentrations peak most often in March and April. But, most striped bass larvae hatch from late April to early May (Rutherford \& Houde 1995) when temperatures rise above $12^{\circ} \mathrm{C}$ (Secor \& Houde 1995), indicating potential for frequent mismatches between prey availability and larval striped bass production. The strongly positive relationship ( $\mathrm{p}<0.01, \mathrm{r}=+0.85$ ) between the day of peak zooplankton concentration and YOY recruitment strength (Fig. 8) indicates that matches occur in years when zooplankton production, especially Eurytemora affinis, peaks in May, as observed in 1993 and 1996. Increased precipitation and freshwater flows during late winter and spring are associated with increased abundances of E. affinis (Wood 2000, Kimmel \& Roman 2004). While E. affinis usually peaks in March or April in Chesapeake Bay (Kimmel \& Roman 2004), peak concentrations occur or extend into May in years when a climate pattern termed the 'Ohio Valley High' (cool and wet) persists through March (Wood 2000) and match the occurrences of peak abundance in striped bass larvae.

The other important prey, Bosmina longirostris, peaks more consistently, usually in May and overlaps peak production of striped bass larvae. This temporal consistency in overlapping may ensure that some larvae encounter sufficient prey in all years. In the Hudson River, B. longirostris also blooms predictably in late May to mid-June, when its concentration surges from 100 to 100000 ind. $\mathrm{m}^{-3}$ and striped bass larvae exhibit positive selectivity for this important prey (Limburg et al. 1997). In the Patuxent River, B. longirostris is second only to Eurytemora affinis in importance as prey, although it is not positively selected by striped bass larvae (Campfield 2004).

\section{The ETM and recruitment success}

It was hypothesized that freshwater flow controls recruitment by its effect on the overlap of temperature/salinity zones preferred by larvae and the elevated secondary productivity in the ETM (North \& Houde 2006). Our results are generally consistent with this hypothesis, although we found that distributions of larval striped bass are not closely coupled to the ETM in all years. In wet years, down-estuary displacement of eggs and yolk-sac larvae enhances the degree of overlap between feeding-stage larvae and the ETM. In the wet year of 2003, larvae tended to occur $>20 \mathrm{~km}$ further down-estuary and were more associated with the ETM than in the dry year of 2002. Recruitment of YOY juveniles was nearly 9-fold higher in 2003 than in 2002.

The ETM with its associated salt front is a compressed frontal feature in estuaries and, as such, is expected to aggregate prey and potentially enhance feeding opportunities and growth of fish larvae. Frontal features, in general, enhance prey availability, feeding success, or growth of marine and estuarine fish 
larvae (Grimes \& Kingsford 1996). There are many examples of such enhancements, e.g. larval cod Gadus morhua (Munk 2007), Japanese sand lance Ammodytes personatus (Nagano et al. 2001), dab Limanda limanda (Lee et al. 2007), sprat Sprattus sprattus (Munk 1993), and yellowfin tuna Thunnus albacares (Lang et al. 1994) in tidal, thermohaline, and river plume fronts.

The ETM in Chesapeake Bay appears to support retention and high production of zooplankton eaten by striped bass larvae (Roman et al. 2001, North \& Houde 2006). High freshwater flows increase estuarine gravitational circulation (Hetland \& Geyer 2004) and may favor higher zooplankton production in addition to retention of particles, including detritus, zooplankton, and larval fish at the salt front and ETM. During wet years, when gravitational circulation is enhanced, Eurytemora affinis abundance increases in Chesapeake Bay (Kimmel et al. 2006) and its center of abundance shifts down-estuary with the ETM. In the 2 wettest years in our analyses (1996 and 2003), there were notable aggregations of zooplankton and striped bass larvae in the ETM and salt front (Fig. 5). In 2003, our diet analysis indicated a high percentage (91\%) of successful, first-feeding striped bass larvae. In contrast, under average (2001) or dry (1999 and 2002) hydrological conditions, concentrations of larvae in the ETM were lower, suggesting that the ETM was less important as a nursery habitat. In 2001 , only $35 \%$ of firstfeeding striped bass larvae had fed successfully.

Dynamics and properties of ETMs and salt fronts probably play a role in controlling recruitment of striped bass in other sub-estuaries and tributaries of Chesapeake Bay. Releases of chemically marked striped bass larvae in the tidal Patuxent River at and up-river of the salt front yielded up-river recaptures, but releases below the salt front resulted in no recaptures, suggesting that the ETM/salt front supported retention (Secor et al. 1995). In the tidal Nanticoke River in 1992 and 1993, Houde \& Secor (1996) reported that most naturally produced and recaptured hatchery-source, striped bass larvae occurred immediately up-river of the ETM/salt front. Consistent with our analysis of upper bay striped bass in 1993, recruitment in the Nanticoke was >2-fold higher in 1993, when high freshwater flow displaced the salt front downriver, resulting in a larger nursery volume up-river of the front than in a contrasting dry year, 1992.

\section{Recruitment model}

We developed a relatively simple, predictive model that describes and forecasts striped bass YOY recruitments, based on temperature and hydrological condi- tions in the upper Chesapeake Bay. The model was successful in describing age-0 recruitment of striped bass $\left(\mathrm{R}^{2}=0.65\right)$, and it successfully forecasted age-0 recruitment in 2 of 3 recent years (Fig. 9). The very poor age-0 recruitment observed in 2008 was substantially lower than that we forecasted, suggesting that important factors were unaccounted for in this year.

We did not include adult stock in our model because spawner biomass alone explains little of the interannual variability in striped bass recruitment. A Ricker spawner-recruit model that we fit to upper bay adult biomass data (Maryland DNR gillnet monitoring) for the years from 1985 to 2007 explained only $2 \%$ of the variability in YOY recruitment compared to a much higher percentage (46\%) explained by a Ricker model including both freshwater flow and adult biomass. In an earlier analysis that included data for the years from 1987 to 1999, Ricker models without and with freshwater flow explained 3 and $44 \%$, respectively, of the variability in recruitment (North \& Houde 2003).

Our 2-variable regression model successfully described and predicted recruitment and was helpful in explaining the process. Spring freshwater flow and temperature largely control the seasonal timing of production and abundance of mesozooplankton prey, as well as the degree of spatial overlap between striped bass larvae and prey. The importance of freshwater flow in controlling survival of striped bass larvae in Chesapeake Bay (Houde \& Secor 1996, McGovern \& Olney 1996, Wood 2000, North \& Houde 2001) and elsewhere (Turner \& Chadwick 1972, Kimmerer et al. 2001) had been recognized previously. Down-estuary displacement of the salt front and a concomitant increase in volume of freshwater and low-salinity habitat up-estuary of the front have been proposed to explain the positive effects of freshwater on striped bass in the Nanticoke River (Secor \& Houde 1996) and in the San Francisco Bay estuary (Kimmerer et al. 2009).

Zooplankton is not included explicitly in our recruitment model, because data on abundance and seasonality of zooplankton were no longer available after 2002 (CB-Program 2002). In the upper Chesapeake Bay, abundance and distribution of the most important prey (Eurytemora affinis) of striped bass larvae, are controlled largely by the level of freshwater flow (Kimmel \& Roman 2004, Lloyd 2006). Temperature controls the timing of striped bass spawning and larval production (Secor \& Houde 1995) and plays a role in the production of E. affinis (Devreker et al. 2006). Including the mean zooplankton concentration for the periodfrom April to May in the years from 1985 to 2002 as an independent variable in our model slightly improved the model fit (Akaike's information criterion $=97.2$ to 94.6) for the $18 \mathrm{yr}$ recruitment time series when zoo- 
plankton data were available. Presumably, a zooplankton variable would improve the model's predictive and forecasting capability if zooplankton data were presently available.

\section{Management implications}

Our findings, potentially, will find application in management planning for the striped bass fishery. The recruitment model has the capability of forecasting YOY juvenile abundances. The model is underpinned by an enhanced understanding of the mechanisms by which hydrological conditions affect recruitment and is supported by new information on the spatial and temporal processes that control year-class strength of YOY striped bass in Chesapeake Bay.

Disentangling the effects of environmental variability from the effects of adult biomass and demographics on recruitment may contribute to effective management of the striped bass resource. Uncertainty in the stock-recruitment relationships used in striped bass stock assessment models (ASMFC 2008) could be reduced by accounting for environmental effects. Striped bass have the characteristics of a fish stock that could benefit from recruitment-process information in stock assessments, i.e. a strong environment-recruitment relationship and periodic dominance in the fishery by strong year classes (De Oliveira \& Butterworth 2005). Ecosystem-based approaches to the management of striped bass and other fisheries are under development for Chesapeake Bay (EBFMCB 2010), drawing more attention to the urgency of understanding how environmental variability influences pre-recruit dynamics. At present, environmental indicators are not included in management planning or reference points for Chesapeake Bay striped bass. Our analysis of spatiotemporal variability in hydrological factors and zooplankton prey availability, and their effects on early life survival, could potentially contribute an important impetus to ecosystem-based plans for the management of striped bass.

Acknowledgements. We appreciate the dedicated work of J. Bichy, L. Beaven, S. Gibson, and C. Lozano, who assisted in the field and laboratory. Reviews and editorial comments on an early version of the manuscript were provided by X. Zhang and W. Connelly. We appreciate insights provided by E. North and L. Sanford on ETM biophysics and by R. Wood on climatology. M. Roman provided insights on zooplankton and acoustic data used to estimate zooplankton abundance. E. Durrell provided information on sampling and data from the Maryland Department of Natural Resources (MDDNR) juvenile fish survey. We are grateful for support provided by the captains and crews on board the RV 'Orion', RV 'Aquarius', and RV 'Cape Henlopen'. This research was supported by US National Science Foundation Grants No. OCE-0002543 and OCE-0453905 and a Mary- land Sea Grant Graduate Research Fellowship. We also thank MDDNR and the National Oceanic and Atmospheric Administration Cooperative Oxford Laboratory for partial support during the preparation of this manuscript.

\section{LITERATURE CITED}

Akaike H (1974) A new look at the statistical model identification. IEEE Trans Automat Contr 19:716-723

ASMFC (Atlantic States Marine Fisheries Commission) (2008) Atlantic States Marine Fisheries Commission Atlantic striped bass stock assessment subcommittee meeting report. ASMFC, Washington, DC

Beaven M, Mihursky J (1980) Food and feeding habits of larval striped bass: an analysis of larval striped bass stomachs from 1976 Potomac Estuary collections (Potomac River Fisheries Program). Rep Md Univ Chesapeake Biol Lab, UMCEES, Solomons, MD

Boynton WR, Boicourt W, Brandt S, Hagy J and others (1997) Interactions between physics and biology in the estuarine turbidity maximum (ETM) of Chesapeake Bay, USA. ICES CM 1997/S:11

Campfield PA (2004) Ichthyoplankton community structure and feeding ecology in the Patuxent River estuarine transition zone (Maryland). Masters thesis, University of Maryland, Solomons, MD

CB-Program (2002) Chesapeake baywide CBP plankton database 1984-present. Chesapeake Bay Program, Annapolis, MD. Available at: www.chesapeakebay.net/data_plankton. aspx (accessed in 2006)

Chesney EJ Jr (1989) Estimating the food requirements of striped bass larvae Morone saxatilis: effects of light, turbidity and turbulence. Mar Ecol Prog Ser 53:191-200

Chick JH, Van Den Avyle MJ (1999a) Zooplankton variability and larval striped bass foraging: evaluating potential match/mismatch regulation. Ecol Appl 9:320-334

Chick JH, Van Den Avyle MJ (1999b) Effects of zooplankton spatial variation on growth of larval striped bass: an experimental approach. Trans Am Fish Soc 128:339-351

> Cowan JH Jr, Rose KA, Rutherford ES, Houde ED (1993) Individual-based model of young-of-the-year striped bass population dynamics. 2. Factors affecting recruitment in the Potomac River, Maryland. Trans Am Fish Soc 122: $439-458$

Cushing DH (1990) Plankton production and year-class strength in fish populations: an update of the match/mismatch hypothesis. Adv Mar Biol 26:249-294

De Oliveira JA, Butterworth DS (2005) Potential use of environmental indices to reduce risk and/or increase yield in the South African anchovy fishery. Afr J Mar Sci 27: 1191-1203

> Devreker D, Souissia S, Forget-Lerayb J, Leboulengerb F (2006) Effects of salinity and temperature on the postembryonic development of Eurytemora affinis (Copepoda; Calanoida) from the Seine estuary: a laboratory study. J Plankton Res 29:i117-i133

Dodson JJ, Dauvin JC, Ingram RG, d'Anglejan B (1989) Abundance of larval rainbow smelt Osmerus mordax in relation to the maximum turbidity zone and associated macroplanktonic fauna of the middle St. Lawrence Estuary. Estuaries 12:66-81

Durell EQ, Weedon C (2009) Striped bass seine survey juvenile index web page. Maryland Department of Natural Resources, Fisheries Service, Annapolis, MD. Available at www.dnr.state.md.us/fisheries/juvindex/index. html (accessed Nov 1, 2009) 
Eldridge MB, Whipple JA, Eng D, Bowers MJ, Jarvis BM (1981) Effects of food and feeding factors on laboratoryreared striped bass larvae. Trans Am Fish Soc 110:111-120

EBFMCB (2010) Ecosystem-based fishery mnagement in Chesapeake Bay. Maryland Sea Grant, College Park, MD. Available at http://www.mdsg.umd.edu/programs/policy/ ebfm/ (accessed in May 2010)

Eldridge MB, Whipple JA, Bowers MJ (1982) Bioenergetics and growth of striped bass, Morone saxatilis, embryos and larvae. Fish Bull 80:461-474

Grimes CB, Kingsford MJ (1996) How do riverine plumes of different sizes influence fish larvae: Do they enhance recruitment? Mar Freshw Res 47:191-208

> Hetland RD, Geyer WR (2004) An idealized study of the structure of long, partially mixed estuaries. J Phys Oceanogr $34: 2677-2691$

Hjort J (1914) Fluctuations in the great fisheries of northern Europe. Rapp PV Reun Cons Int Explor Mer 20:1-227

Holliday DV, Pieper RE (1995) Bioacoustical oceanography at high frequencies. ICES J Mar Sci 52:279-296

Houde ED (1996) Evaluating stage-specific survival during the early life of fish. In: Watanabe Y, Yamashita Y, Oozeki Y (eds) Proceedings of an international workshop: survival strategies in early life stages of marine resources. AA Balkema Publishers, Brookfield, VT, p 51-66

Houde ED (1997) Patterns and trends in larval-stage growth and mortality in teleost fish. J Fish Biol 51:52-83

Houde ED (2008) Emerging from Hjort's shadow. J Northwest Atl Fish Sci 41:53-70

Houde ED, Secor DH (1996) Episodic water quality events and striped bass recruitment: larval mark-recapture experiments in the Nanticoke River: final report to Maryland Department of Natural Resources, Chesapeake Bay Research and Monitoring Division. Contract number CB93-006-002, State of Maryland, Department of Natural Resources, Chesapeake Bay and Watershed Programs, Monitoring and Non-tidal Assessment, Annapolis, MD

Kimmel DG, Roman MR (2004) Long-term trends in mesozooplankton abundance in Chesapeake Bay, USA: influence of freshwater input. Mar Ecol Prog Ser 267:71-83

Kimmel DG, Roman MR, Zhang X (2006) Spatial and temporal variability in factors affecting mesozooplankton dynamics in Chesapeake Bay: evidence from biomass size spectra. Limnol Oceanogr 51:131-141

Kimmerer WJ, Cowan JH Jr, Miller LW, Rose KA (2001) Analysis of an estuarine striped bass population: effects of environmental conditions during early life. Estuaries 24:557-575

Kimmerer WJ, Gross ES, Macwilliams ML (2009) Is the response of estuarine nekton to freshwater flow in the San Francisco estuary explained by variation in habitat volume? Estuaries Coasts 32:375-389

Lang KL, Grimes CB, Shaw RF (1994) Variations in the age and growth of yellowfin tuna larvae, Thunnus albacares, collected about the Mississipi River plume. Environ Biol Fishes 39:259-270

Lee O, Danilowicz BS, Nash RDM (2007) Small-scale variability in growth and condition of dab Limanda limanda (L.) larvae in relation to an Irish Sea tidal-mixing front off the west coast of the Isle of Man. J Fish Biol 71:1056-1068

Limburg KE, Pace ML, Fischer D, Arend KK (1997) Consumption, selectivity, and use of zooplankton by larval striped bass and white perch in a seasonally pulsed estuary. Trans Am Fish Soc 126:607-621

Limburg KE, Pace ML, Arend KK (1999) Growth, mortality, and recruitment of larval Morone spp. in relation to food availability and temperature in the Hudson River. Fish Bull 97:80-91
Lloyd SS (2006) Zooplankton ecology in the Chesapeake Bay estuarine turbidity maximum, with emphasis on the calanoid copepod Eurytemora affinis. Diss Abstr Int B Sci Eng 67(3):1315. Available at: www.proquest.com/en-US/ catalogs/databases/detail/dai.shtml (accessed Sep 20, 2009)

> Logan DT (1985) Environmental variation and striped bass population dynamics: a size-dependent mortality model. Estuaries 8:28-38

MacKenzie BR, Leggett WC, Peters RH (1990) Estimating larval fish ingestion rates: Can laboratory derived values be reliably extrapolated to the wild? Mar Ecol Prog Ser 67: 209-225

Mansueti RJ (1958) Eggs, larvae, and young of striped bass, Roccus saxatilis. Rep Md Univ Chesapeake Biol Lab 112: $1-35$

Martino EJ (2008) Environmental controls and biological constraints on recruitment of striped bass Morone saxatilis in Chesapeake Bay. Doctoral dissertation, University of Maryland, College Park, MD

$>$ McGovern JC, Olney JE (1996) Factors affecting survival of early life stages and subsequent recruitment of striped bass on the Pamunkey River, Virginia. Can J Fish Aquat Sci 53:1713-1726

Merriman D (1941) Studies on the striped bass Roccus saxatilis of the Atlantic coast. US Fish Wildl Serv Fish Bull 50(35):1-77

Mihursky JA, Setzler-Hamilton E, Martin FD, Jones P, Ripple K, Beaven M, Drewry G (1981) Resource utilization by larval fish in the upper Potomac Estuary. Estuaries 4:245

Munk P (1993) Differential growth of larval sprat Sprattus sprattus across a tidal front in the eastern North Sea. Mar Ecol Prog Ser 99:17-27

Munk P (2007) Cross-frontal variation in growth rate and prey availability of larval North Sea cod Gadus morhua. Mar Ecol Prog Ser 334:225-235

> Nagano N, Iwatsuki Y, Okazaki Y, Nakata H (2001) Feeding strategy of Japanese sand lance larvae in relation to ciliated protozoa in the vicinity of a thermohaline front. J Oceanogr 57:155-163

> North EW, Houde ED (2001) Retention of white perch and striped bass larvae: biological-physical interactions in Chesapeake Bay estuarine turbidity maximum. Estuaries 24:756-769

North EW, Houde ED (2003) Linking ETM physics, zooplankton prey, and fish early-life histories to white perch Morone americana and striped bass $M$. saxatilis recruitment success. Mar Ecol Prog Ser 260:219-236

> North EW, Houde ED (2006) Retention mechanisms of white perch Morone americana and striped bass Morone saxatilis early-life stages in an estuarine turbidity maximum: an integrative fixed-location and mapping approach. Fish Oceanogr 15:429-450

Pepin P (2004) Early life history studies of prey-predator interactions: quantifying the stochastic individual responses to environmental variability. Can J Fish Aquat Sci 61: 659-671

Roman MR, Holliday DV, Sanford LP (2001) Temporal and spatial patterns of zooplankton in the Chesapeake Bay turbidity maximum. Mar Ecol Prog Ser 213:215-227

Rutherford ES, Houde ED (1995) The influence of temperature on cohort-specific growth, survival, and recruitment of striped bass, Morone saxatilis, larvae in Chesapeake Bay. Fish Bull 93:315-332

Rutherford ES, Houde ED, Nyman RM (1997) Relationship of larval-stage growth and mortality to recruitment of striped bass, Morone saxatilis, in Chesapeake Bay. Estuaries 20: 174-198 
Sanford LP, Suttles SE, Halka JP (2001) Reconsidering the physics of the Chesapeake Bay Estuarine Turbidity Maximum. Estuaries 24(5):655-669

Schubel JR (1968) Turbidity maximum of the northern Chesapeake Bay. Science 161:1013-1015

Secor DH, Houde ED (1995) Temperature effects on the timing of striped bass egg production, larval viability, and recruitment potential in the Patuxent River (Chesapeake Bay). Estuaries 18:527-544

Secor DH, Houde ED, Monteleone DM (1995) A mark-release experiment on larval striped bass Morone saxatilis in a Chesapeake Bay tributary. ICES J Mar Sci 52:87-101

Setzler-Hamilton EM, Wright DA, Martin FD, Millsaps CV, Whitlow SI (1987) Analysis of nutritional condition and its use in predicting striped bass recruitment: field studies. In: Proc 10th Annu Larval Fish Conf. Am Fish Soc Symp Ser 2: 115-128

Shoji J, North EW, Houde ED (2005) The feeding ecology of Morone americana larvae in the Chesapeake Bay estuarine turbidity maximum: the influence of physical conditions and prey concentrations. J Fish Biol 66:1328-1341

Sirois P, Dodson JJ (2000a) Critical periods and growthdependent survival of larvae of an estuarine fish, the rain-

Editorial responsibility: Hans Heinrich Janssen,

Oldendorf/Luhe, Germany bow smelt Osmerus mordax. Mar Ecol Prog Ser 203: 233-245

Sirois P, Dodson JJ (2000b) Influence of turbidity, food density and parasites on the ingestion and growth of larval rainbow smelt Osmerus mordax in an estuarine turbidity maximum. Mar Ecol Prog Ser 193:167-179

Tsai CF (1991) Prey density requirements of the striped bass, Morone saxatilis (Walbaum), larvae. Estuaries 14:207-217

> Turner JL, Chadwick HK (1972) Distribution and abundance of young-of-the-year striped bass, Morone saxatilis, in relation to river flow in the Sacramento-San Joaquin Estuary. Trans Am Fish Soc 101:442-452

Ulanowicz RE, Polgar TT (1980) Influences of anadromous spawning behavior and optimal environmental conditions upon striped bass Morone saxatilis year-class success. Can J Fish Aquat Sci 37:143-154

Uphoff JH Jr (1989) Environmental effects on survival of eggs, larvae, and juveniles of striped bass in the Choptank Rver, Maryland. Trans Am Fish Soc 118:251-263

Wood RJ (2000) Synoptic scale climatic forcing of multispecies fish recruitment patterns in Chesapeake Bay. College of William and Mary, School of Marine Science, Williamsburg, VA

Submitted: July 20, 2009; Accepted: March 16, 2010

Proofs received from author(s): June 3, 2010 